\title{
COMBINATIONS OF CORIANDER AND SALAD ROCKET CULTIVARS IN BICROPPING SYSTEMS INTERCROPPED WITH CARROT CULTIVARS ${ }^{1}$
}

\author{
JOSIMAR NOGUEORA DA SILVA ${ }^{2}$, FRANCISCO BEZERRA NETO ${ }^{3 *}$, JAILMA SUERDA SILVA DE LIMA ${ }^{3}$, \\ GARDÊNIA SILVANA DE OLIVEIRA RODRIGUES ${ }^{3}$, AURÉLIO PAES BARROS JÚNIOR ${ }^{3}$, ARIDÊNIA PEIXOTO \\ CHAVES $^{2}$
}

\begin{abstract}
The objective of this study was to evaluate combinations of coriander and salad rocket cultivars in bicropping systems intercropped with carrot cultivars in strips under the conditions of Mossoró-RN. The work was conducted at the Experimental Farm Rafael Fernandes from July to December 2014. The experimental design was a randomized complete block design with four replications and treatments arranged in a factorial design with additional treatments of type $2 \times 2 \times 2+2$. The treatments consisted of the combinations of two coriander cultivars (Verdão and Português) and two rocket cultivars (Cultivada and Folha Larga), intercropped with two carrot cultivars (Brasília and Esplanada) plus two additional treatments, where the first are the cultivars in monocropping and the second the types of cropping (single and intercropped). We evaluated fresh and dry shoot mass in coriander and rocket and fresh and dry shoot mass as well as dry root mass, commercial and total root productivity, and classified root productivity in carrot. In the intercropping systems we evaluated land equivalent ratio, productive efficiency index, and score of the canonical variable, besides the indicators of economic efficiency (gross income, net income, rate of return and profit margin). Highest agroeconomic efficiency in intercropping systems was achieved with the combination of the coriander cultivar 'Verdão' and the rocket cultivars 'Folha Larga' or 'Cultivada' as well as the carrot cultivars 'Brasília' or 'Esplanada'. Regardless of the tested cultivar combinations, systems with coriander and salad rocket intercropped with carrot showed higher efficiency than monocropping systems.
\end{abstract}

Keywords: Daucus carota L.. Coriandrum sativum L.. Eruca sativa L.. Polyculture.

\section{COMBINAÇÕES DE CULTIVARES DE COENTRO E RÚCULA EM BICULTIVO CONSORCIADAS COM CULTIVARES DE CENOURA}

\begin{abstract}
RESUMO - O objetivo deste trabalho foi avaliar combinações de cultivares de coentro e rúcula em bicultivo consorciadas com cultivares de cenoura em faixas, nas condições de Mossoró - RN. O trabalho foi realizado na Fazenda Experimental Rafael Fernandes de julho a dezembro de 2014. O delineamento experimental foi em blocos completos casualizados, com quatro repetições e os tratamentos arranjados em um esquema fatorial com tratamentos adicionais do tipo $2 \times 2 \times 2+2$. Os tratamentos consistiram da combinação de duas cultivares de coentro (Verdão e Português) e duas cultivares de rúcula (Cultivada e Folha Larga), consorciadas com duas cultivares de cenoura (Brasília e da Esplanada), mais dois tratamentos adicionais, onde o primeiro são as cultivares em monocultivo e o segundo os sistemas de cultivo (solteiro e consorciado). Foram avaliadas massa fresca e seca da parte aérea em coentro e rúcula e massa fresca e seca da parte aérea, bem como, massa de raízes seca, produtividade de raízes comercial e total e produtividade de raízes classificadas na cenoura. No sistema de consórcio avaliaram-se: índice de uso eficiente da terra, índice de eficiência produtiva, e escore da variável canônica, além dos indicadores de eficiência econômica (renda bruta, renda líquido, taxa de retorno e índice de lucratividade). A maior eficiência agroeconômica nos sistemas consorciados foi conseguida com a combinação da cultivar de coentro 'Verdão' e as cultivares de rúcula 'Folha Larga' ou 'Cultivada', bem como, as cultivares de cenoura 'Brasília' ou 'Esplanada'. Independentemente das combinações das cultivares testadas, sistemas com coentro e rúcula em consórcio com cenoura mostraram maior eficiência do que os monocultivos.
\end{abstract}

Palavras-chave: Daucus carota L.. Coriandrum sativum L.. Eruca sativa L.. Policultivo.

\footnotetext{
*Corresponding author

${ }^{1}$ Received for publication in $03 / 07 / 2016$; accepted in $07 / 11 / 2016$.

Paper extracted from the master thesis of the first author.

${ }^{2}$ Department of Crop Science, Program in Plant Science, Universidade Federal Rural do Semi-Árido, Mossoró, RN, Brazil; josimar2160@hotmail.com, aridenia.peixoto@hotmail.com.

${ }^{3}$ Department of Crop Science, Universidade Federal Rural do Semi-Árido, Mossoró, RN, Brazil; bezerra@ufersa.edu.br, jailma@ufersa.edu.br, gardeniavg@yahoo.com.br, aurelio.barros@ufersa.edu.br.
} 


\section{INTRODUCTION}

Intercropping systems, simultaneous cropping systems, or polycultures are production cropping systems which grow more than one crop per unit area. Especially in small, family run farms, such systems are the key factor in ensuring economic viability, as they guarantee maximum returns through on optimal use of inputs and labor (SILVA et al., 2011).

Intercropping systems make use of synergistic effect or offset the impact of one culture on other cultures, thereby enabling higher yields (REZENDE et al., 2006); when performed in agroecological molds, they present several advantages in production, nutritional, economic, and environmental aspects (OLIVEIRA et al., 2004). In addition, this agrosystem offers greater productivity, economic, and biological stability as well as a more efficient use of available resources such as soil, water, light, and nutrients (SEDIYAMA; SANTOS; LIMA, 2014). However, to obtain satisfactory agroeconomic results, proper management of the production factors is crucial.

One of these factors is the combination of species or cultivars, which can considerably improve the productive performance of vegetable crops through combined resource use (BEZERRA NETO et al., 2003). As different crops occupy different ecological niches, they may maximize light use and nutrient absorption (OLIVEIRA et al., 2004).

Several studies on vegetable crop combinations have been performed previously. For example, Lima et al. (2010), studying rocket cultivars intercropped with carrot, observed better performance of the rocket cultivar Folha Larga when intercropped with Brasilia carrot. Similarly, Bezerra Neto et al. (2007) analyzed the intercropping of carrot and lettuce using univariate and multivariate methods; they found that in intercropping systems using carrot Alvorada and lettuce Lucy Brown or Brasilia carrot and lettuce Lucy Brown are those to be indicated to the producer, respectively. Evaluating the performance of four cultivars of loose-leaf lettuce and carrot, Bezerra Neto et al. (2003) observed that intercropping systems using the carrot cultivar Brasilia and the lettuce cultivar Verdinha obtained higher agroeconomic viability, with a land equivalent ratio of 1.19 and a rate of return of $\mathrm{R} \$$ 3.00 .

Therefore, the objective of this study was to evaluate combinations of coriander and rocket cultivars in bicropping systems with carrot cultivars in strips in Mossoró - RN.

\section{MATERIAL AND METHODS}

The experiment was conducted at the
Experimental Farm Rafael Fernandes, located in the Alagoinha district, $20 \mathrm{~km}$ from Mossoró-RN ( $37^{\circ} 31^{\prime} 16^{\prime \prime} \mathrm{S}$ and $5^{\circ} 27^{\prime} 34^{\prime \prime} \mathrm{W}, 34 \mathrm{~m}$ altitude), from July to December 2014. During the trial period, the area experienced no rainfall and average, maximum, and minimum temperatures of $28.5,33.4$, and 23.03 ${ }^{\circ} \mathrm{C}$, respectively. Relative humidity was $62 \%$ and solar radiation $901 \mathrm{kjm}^{-2}$.

Prior to the experiment, soil samples were taken at a depth of $0-20 \mathrm{~cm}$, air dried, and sieved through a $2 \mathrm{~mm}$ mesh. Processing and analysis took place at the Laboratory of Chemistry and Fertility of Soils of the Universidade Federal Rural do Semi-Árido (UFERSA), with the following results: $\mathrm{C}=0.59 \mathrm{~g} \mathrm{~kg}^{-1} ; \mathrm{pH}=6.12 ; \mathrm{P}=3.75 \mathrm{mg} \mathrm{dm}^{-3}$; $\mathrm{K}=70.82 \mathrm{mg} \mathrm{dm} ; \mathrm{Ca}^{2+}=1.98 \mathrm{cmol}_{\mathrm{c}} \mathrm{dm}^{-3}$; $\mathrm{Mg}^{2+}=0.68 \mathrm{cmol}_{\mathrm{c}} \mathrm{dm}^{-3} ; \mathrm{Na}^{+}=7.8 \mathrm{mg} \mathrm{dm}$; EC $0.18=\mathrm{dS} \mathrm{m}{ }^{-1}$; M.O. $=7.82 \mathrm{~g} \mathrm{~kg}^{-1}$; Sum of bases $=2.88 \mathrm{cmol}_{\mathrm{c}} \mathrm{dm}^{-3} ;$ Cation exchange capacity $=3.48 \mathrm{cmol}_{\mathrm{c}} \mathrm{dm}^{-3}$; Exchangeable sodium percentage $=1 \%$, and Base saturation $=83 \%$.

The experimental design was a randomized complete block design with four replications and treatments arranged in a factorial scheme with additional treatments of type $2 \times 2 \times 2+2$. The treatments consisted of the combination of two coriander cultivars (Verdão and Português) and two rocket cultivars (Cultivada and Folha Larga), intercropped with two carrot cultivars (Brasília and Esplanada), plus two additional treatments, single cultivars and cropping types (monocropping and intercropping).

In each experimental plot, intercropping was established in alternating strips of the component cultures, where each strip was formed by four rows and the cultures arranged in the proportion of $25 \%$ of the area for coriander, $25 \%$ for rocket, and $50 \%$ for carrot, flanked by two border rows of carrot on one side and two rows of broadleaves on the other side (Figure 1).

The total area of the plot was $4.80 \mathrm{~m}^{2}$, with a harvest area of $3.20 \mathrm{~m}^{2}$. Spacing for both cultures (carrot and broadleaves) was $0.20 \mathrm{~m} \mathrm{x} 0.05 \mathrm{~m}$, with two plants per hole for broadleaves (rocket and coriander) and one plant per hole for carrot, totaling 160 plants of each crop in the harvest area, corresponding to a population of $1,000,000$ plants per hectare for coriander and rocket (LIMA et al., 2007; FREITAS et al., 2009) and 500,000 plants per hectare for the culture of carrot, which are recommended densities for this region (OLIVEIRA et al., 2004).

The plots in the monocropping system had a total area of $1.44 \mathrm{~m}^{2}$, with a harvest area of $0.80 \mathrm{~m}^{2}$, containing 80 coriander and 80 rocket plants at a spacing of $0.20 \times 0.05 \mathrm{~m}$; for carrot, the harvest area was $0.80 \mathrm{~m}^{2}$, containing 40 plants at a spacing of $0.20 \times 0.10 \mathrm{~m}$. 


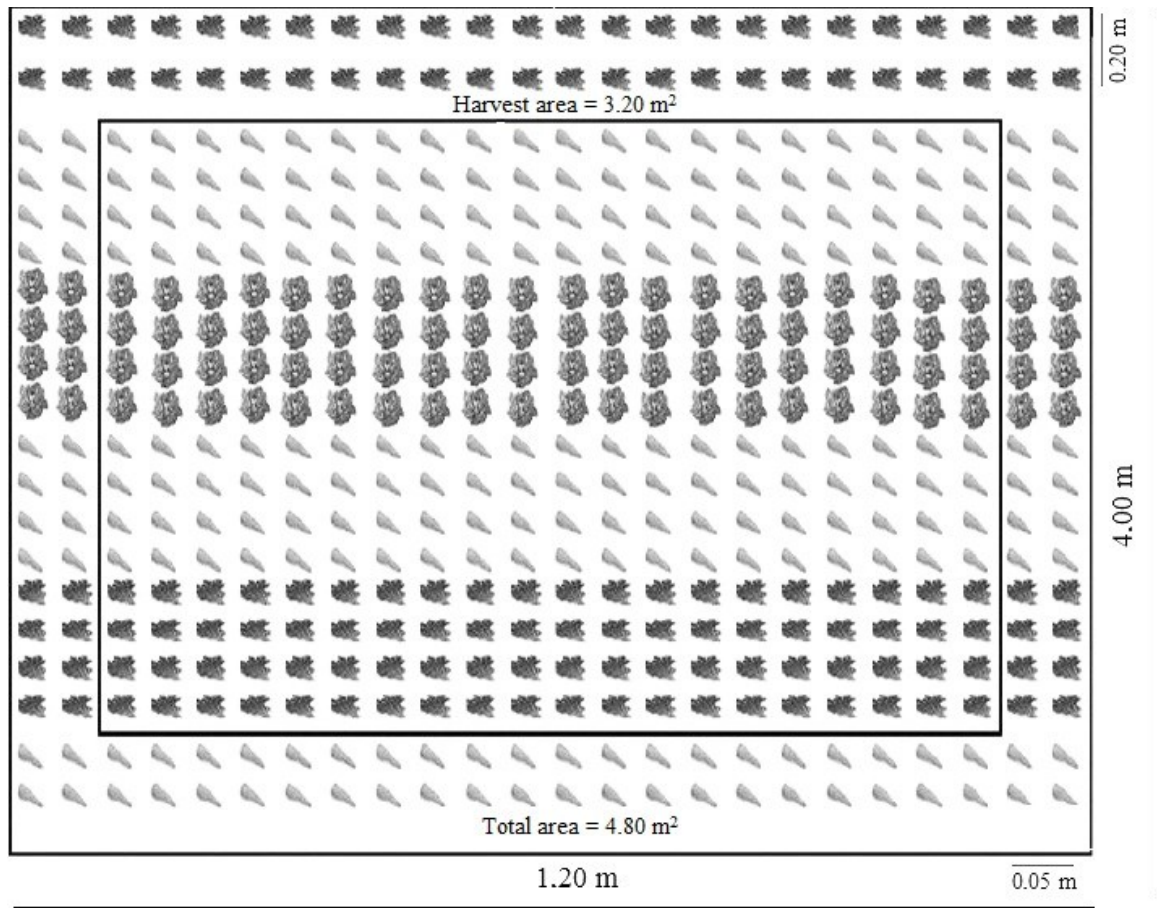

Figure 1. Graphical representation of the experimental plot in the intercropping system with coriander ( carrot $(\$)$ and rocket ( ).

Soil preparation consisted of harrowing, followed by the lifting of beds, with a $1.20 \mathrm{~m}$ wide seedbed tiller, with six spades. Subsequently, one solarization period of 45 days was carried out in order to reduce phytopathogen populations of the soil (SILVA et al., 2006).

Hairy woodrose (Merremia aegyptia L.) green manure was collected from native vegetation near Mossoró-RN, before the beginning of flowering. After collection, the plants were mashed in a conventional forage machine to obtain fragmented particles with a particle size of 2.0 to $3.0 \mathrm{~cm}$. Particles were dried in sunlight to reach a moisture content of $10 \%$ and a subsample was subjected to laboratory analysis, obtaining the following results: $15.3 \mathrm{~g} \mathrm{~kg}^{-1} \mathrm{~N} ; 4.0 \mathrm{~g} \mathrm{~kg}^{-1} \mathrm{P}$; $15.7 \mathrm{~g} \mathrm{~kg}^{-1} \mathrm{~K} ; 9.3 \mathrm{~g} \mathrm{~kg}^{-1} \mathrm{Ca}$, and $7.03 \mathrm{~g} \mathrm{~kg}^{-1} \mathrm{Mg}$, a carbon/nitrogen ratio of 25: 1 .

Green manure was incorporated into the intercropping and monocropping plots of carrots, with $50 \%$ of hairy woodrose biomass into all planting beds on August 4, 2014, 21 days before sowing of the component crops; and the remaining $50 \%$ were incorporated 45 days after carrot planting. The broadleaf vegetable crops were planted in two successive croppings (bicropping) during carrot cultivation, according to the methodology described in Oliveira (2012), using the recommended dose of $24 \mathrm{t} \mathrm{ha}^{-1}$.

The doses used in monocroppings of carrot, coriander, and rocket were of 18, 14, and $12 \mathrm{t} \mathrm{ha}^{-1}$, respectively, based on recommendations by Bezerra Neto et al. (2014), Linhares et al. (2012), and Linhares et al. (2008).
Coriander, rocket, and carrot cultivars were sown on August 25, 2014, in direct and simultaneous sowing into holes approximately $2 \mathrm{~cm}$ deep. For rocket and coriander, thinning was performed ten days after sowing (DAS), leaving two plants per hole in the intercropping plots and only one plant per hole in the monocropping plots. For carrot, thinning was performed 16 days after sowing, leaving one plant per hole in the plots of both cropping systems. The second sowing of the rocket and coriander was performed on November 11, 2014, 75 days after carrot sowing. Thinning of the second cultivation of the broadleaf vegetable crops was performed ten days after sowing, also leaving two seedlings per hole in the intercropping and only one seedling per hole in the monocropping plots.

During the experiment, hand-weeding was performed when necessary. To avoid shading of the coriander and rocket plants by the carrot crop, we lifted the carrot branches during cultivation of the second cropping, thereby reducing competition for light. Plants were irrigated daily using a micro-sprinkler with at morning and afternoon, applying approximately $8 \mathrm{~mm} \mathrm{day}^{-1}$ (LIMA et al., 2010) in order to promote soil microbial activity during decomposition.

Rocket and coriander were first harvested on September 24, 2014, 30 days after sowing, and the harvesting of the second cropping occurred on October 1, 2014, 37 days after sowing. Carrots were harvested on November 29, 2014, 96 days after sowing.

In coriander and rocket plants, we evaluated fresh and dry shoot mass by weighing 20 plants. 
Results were expressed in $\mathrm{tha}^{-1}$.

For carrot, we determined fresh and dry shoot mass, dry root mass, and total, commercial, and classified root productivity. Values of fresh and dry shoot mass and dry root mass were obtained from a subsample of 15 plants and expressed in $\mathrm{tha}^{-1}$. Total productivity was determined from the fresh root mass of all plants in the harvest area and expressed in $\mathrm{t} \mathrm{ha}^{-1}$.

Commercial carrot productivity was quantified from the fresh mass of long, medium, and short roots in the harvest area and expressed in $\mathrm{tha}^{-1}$. As commercially relevant produce, we only considered roots free of cracks, bifurcations, nematodes, and mechanical damage.

Root productivity was classified according to length and cross-sectional diameter: long (length of 17 to $25 \mathrm{~cm}$ and diameter $<5 \mathrm{~cm}$ ), medium (length 12 to $17 \mathrm{~cm}$ and diameter $>2.5 \mathrm{~cm}$ ), short (length 5 to $12 \mathrm{~cm}$ and diameter $>1 \mathrm{~cm}$ ), and scrap (roots that do not satisfy these criteria), according to Lana and Vieira (2000).

For all intercropping systems, we evaluated the land equivalent ratio (LER) using the following equation:

$$
\begin{aligned}
& \mathrm{LER}=\left(\mathrm{Y}_{\mathrm{crt} 1} / \mathrm{Y}_{\mathrm{cm} 1}\right)+\left(\mathrm{Y}_{\mathrm{crt} 2} / \mathrm{Y}_{\mathrm{cm} 2}\right)+\left(\mathrm{Y}_{\mathrm{rct} 1} /\right. \\
& \left.\mathrm{Y}_{\mathrm{rm} 1}\right)+\left(\mathrm{Y}_{\mathrm{rct} 2} / \mathrm{Y}_{\mathrm{rm} 2}\right)+\left(\mathrm{Y}_{\mathrm{tcr}} / \mathrm{Y}_{\mathrm{tm}}\right),
\end{aligned}
$$

where $Y_{\text {crt1 }}=$ fresh mass yield of coriander in polyculture with rocket and carrot in the first cropping;

$\mathrm{Y}_{\mathrm{cm} 1}=$ fresh mass yield of coriander in monocropping in the first cropping;

$\mathrm{Y}_{\mathrm{crt} 2}=$ fresh mass yield of coriander in polyculture with rocket and carrot in the second cropping;

$\mathrm{Y}_{\mathrm{cm} 2}=$ fresh mass yield of coriander in monocropping in the second cropping;

$\mathrm{Y}_{\text {rctl }}=$ fresh mass yield of rocket in polyculture with coriander and carrot in the first cropping;

$\mathrm{Y}_{\mathrm{rm} 1}=$ fresh mass yield of rocket in monocrop the first cropping;

$\mathrm{Y}_{\mathrm{rct} 2}=$ fresh mass yield of rocket in polyculture with coriander and carrot in the second cropping;

$\mathrm{Y}_{\mathrm{rm} 2}=$ fresh mass yield of rocket in monocrop in the second crop;

$\mathrm{Y}_{\mathrm{tcr}}=$ commercial productivity of carrot roots in polyculture with coriander and rocket;

$\mathrm{Y}_{\mathrm{tm}}=$ commercial productivity of carrot roots in monocropping.
The values paid to the producers for coriander, rocket, and carrot were $\mathrm{R} \$ 3.80,1.40$, and $1.48 \mathrm{~kg}^{-1}$, respectively. Gross income was obtained by multiplying the crop yield in each treatment by the value of the product paid to the producer. Net income was calculated by subtracting the production costs from the gross income.

These costs were calculated for each treatment based on the cost coefficients of inputs and services used in one hectare of each cultivar of coriander, rocket, and carrot at the experimental level. Local prices of inputs and services in December 2014 were considered and are shown in Table 7.

The rate of return was obtained by the ratio between gross income and total cost, which corresponds to the amount of Reals ( $\mathrm{R} \$$ ) for each Real invested. The profit margin was obtained from the ratio between net income and gross income, expressed as percentage.

The productive efficiency index (PEI) was calculated to evaluate the productive efficiency of each treatment, using the PEI model with constant returns to scale (CHARNES et al., 1978), since there is no evidence of significant scale differences. In addition to other characteristics of each component, we evaluated the score of the canonical variable $(\mathrm{Z})$ using multivariate analysis of variance.

For statistical analysis of the broadleaf vegetable crops data, we used the yield data from two croppings. Univariate analysis of variance for the factorial experiment in a randomized complete block design with additional treatments was performed to evaluate the characteristics studied through the application of SISVAR software (FERREIRA, 2011). A multivariate analysis of variance was performed on the yields of intercropped vegetable crops, as a function of factors-treatments through the same software. Tukey's test at 5\% probability was used to compare average values between cultivars.

\section{RESULTS AND DISCUSSION}

\section{Coriander crop}

We found no interaction between the coriander, rocket, and carrot cultivars in any of the characteristics evaluated (Table 1). However, there was a significant difference between rocket cultivars in fresh and dry shoot mass yields of the coriander in intercropping with rocket and carrot, with the cultivar Folha Larga standing out of the Cultivada (Table 1). 
Table 1. Mean values of fresh shoot mass (FSM) and dry shoot mass (DSM) of coriander as a function of cultivar combinations of coriander, carrot and rocket in monocrop and cropping systems.

\begin{tabular}{ccc}
\hline Cultivar & \multicolumn{2}{c}{ Evaluated characteristics } \\
\hline & FSM $\left(\mathrm{t} \mathrm{ha}^{-1}\right)$ & Coriander cultivars in intercropping \\
\hline Verdão & & $0.22 \mathrm{a}$ \\
Português & $1.97 \mathrm{a}$ & $0.39 \mathrm{a}$ \\
\hline & $1.87 \mathrm{a}$ & Carrot cultivars in intercropping \\
\hline Brasília & $1.91 \mathrm{a}$ & $0.30 \mathrm{a}$ \\
Esplanada & $1.92 \mathrm{a}$ & $0.31 \mathrm{a}$ \\
\hline & & Rocket cultivars in intercropping \\
\hline Cultivada & $1.63 \mathrm{~b}$ & $0.22 \mathrm{~b}$ \\
Folha Larga & $2.20 \mathrm{a}$ & $0.39 \mathrm{a}$ \\
\hline & & Coriander cultivars in monocropping \\
\hline Verdão & $1.26 \mathrm{a}$ & $0.25 \mathrm{~b}$ \\
Português & $1.51 \mathrm{a}$ & $0.42 \mathrm{a}$ \\
\hline Intercropping & $1.92 \mathrm{a}$ & $0.34 \mathrm{a}$ \\
Monocropping & $1.39 \mathrm{~b}$ & $0.31 \mathrm{a}$ \\
\hline
\end{tabular}

Means followed by different lowercase letters in the column differ statistically by Tukey's test at $5 \%$ probability.

For coriander cultivars in monocropping, we observed significant difference between the mean values of DSM, with the Português exceeding the values of Verdão. The differentiation in the performances of coriander cultivars might be related to different temperature and light conditions and different adaptation abilities of these cultivars.

We also observed significant differences in terms of fresh mass yields between the cropping systems, with higher values in the intercropping system than in the monocropping (Table 1). Our results differ from those obtained by Grangeiro et al.
(2011), who found no difference in fresh mass yields of coriander between monocropping and intercropping with beet.

\section{Rocket crop}

There was no significant interaction between the vegetable crops cultivars tested. Similarly, there was no significant difference between cultivars in the intercropping and monocropping and between cultivation systems for any of the characteristics evaluated in rocket (Table 2 ).

Table 2. Mean values of fresh shoot mass (FSM) and dry shoot mass (DSM) of rocket as a function of cultivar combinations of coriander, carrot and rocket in monocrop and cropping systems.

\begin{tabular}{ccc}
\hline Cultivar & \multicolumn{2}{c}{ Evaluated characteristics } \\
\hline & FSM $\left(\mathrm{t} \mathrm{ha}^{-1}\right)$ & DSM $\left(\mathrm{t} \mathrm{ha}^{-1}\right)$ \\
\hline & \multicolumn{2}{c}{ Coriander cultivars in intercropping } \\
\hline Verdão & $4.17 \mathrm{a}$ & $0.80 \mathrm{a}$ \\
Português & $4.11 \mathrm{a}$ & $0.72 \mathrm{a}$ \\
\hline & \multicolumn{2}{c}{ Carrot cultivars in intercropping } \\
\hline Brasília & $4.00 \mathrm{a}$ & $0.78 \mathrm{a}$ \\
Esplanada & $4.27 \mathrm{a}$ & $0.74 \mathrm{a}$ \\
\hline & \multicolumn{3}{c}{ Rocket cultivars in intercropping } \\
\hline Cultivada & $4.49 \mathrm{a}$ & $0.80 \mathrm{a}$ \\
Folha Larga & $3.79 \mathrm{a}$ & $0.72 \mathrm{a}$ \\
\hline & \multicolumn{3}{c}{ Rocket cultivars in monocropping } \\
\hline Cultivada & $3.26 \mathrm{a}$ & $0.74 \mathrm{a}$ \\
Folha Larga & $3.43 \mathrm{a}$ & $0.68 \mathrm{a}$ \\
\hline & \multicolumn{3}{c}{ Cropping systems } \\
\hline Intercropping & $4.14 \mathrm{a}$ & $0.77 \mathrm{a}$ \\
Monocropping & $3.53 \mathrm{a}$ & $0.71 \mathrm{a}$ \\
\hline
\end{tabular}

Means followed by different lowercase letters in the column differ statistically by Tukey's test at $5 \%$ probability. 
When two or more crops are grown simultaneously, each requires adequate space to maximize cooperation and minimize competition. In our study, it is possible that there was a complementarity between both cultivars in the intercropping system, which made it difficult to differentiate one cultivar from another.

Our results are similar to those obtained by Lima et al. (2010), who evaluated the productive performance of carrot and rocket cultivars in strips intercropping system and found no significant interaction between cropping systems and cultivars of carrot and rocket.
There was no interaction between cultivars of coriander, carrot, and rocket in terms of fresh and dry shoot mass and dry root mass. However, we observed significant differences between the mean values of fresh shoot mass between coriander cultivars in the intercropping, in which cultivar Verdão observed higher values than Português, and in the dry root mass between carrot cultivars, with Brasília cultivar having higher values than Esplanada in the intercropping system (Table 3). These differences are likely due to higher adaptation abilities of Verdão and Brasilia cultivars to semi-arid conditions compared to the cultivars Português and Esplanada (LOPES et al., 2008).

\section{Carrot crop}

Table 3. Mean values of fresh shoot mass (FSM) and dry shoot mass (DSM) and dry root mass (DRM) of carrot as a function of cultivar combinations of coriander, carrot and rocket in monocrop and cropping systems.

\begin{tabular}{cccc}
\hline Cultivar & \multicolumn{3}{c}{ Evaluated characteristics } \\
\hline & FSM $\left(\mathrm{t} \mathrm{ha}^{-1}\right)$ & DSM $\left(\mathrm{t} \mathrm{ha}^{-1}\right)$ & DRM $\left(\mathrm{t} \mathrm{ha}^{-1}\right)$ \\
\cline { 2 - 4 } & $3.45 \mathrm{a}$ & Coriander cultivars in intercropping & $2.88 \mathrm{a}$ \\
\hline Verdão & $0.39 \mathrm{a}$ & $2.88 \mathrm{a}$ \\
Português & $2.85 \mathrm{~b}$ & $0.35 \mathrm{a}$ & $3.06 \mathrm{a}$ \\
\hline & & Carrot cultivars in intercropping & $2.71 \mathrm{~b}$ \\
\hline Brasília & $3.16 \mathrm{a}$ & $0.37 \mathrm{a}$ \\
Esplanada & $3.14 \mathrm{a}$ & $0.37 \mathrm{a}$ & $2.78 \mathrm{a}$ \\
\hline & & Rocket cultivars in intercropping \\
\hline Cultivada & $3.20 \mathrm{a}$ & $0.38 \mathrm{a}$ \\
Folha Larga & $3.10 \mathrm{a}$ & $0.36 \mathrm{a}$ & $2.99 \mathrm{a}$ \\
\hline & & Carrot cultivars in monocropping \\
\hline Brasília & $8.61 \mathrm{a}$ & $0.29 \mathrm{a}$ & $2.14 \mathrm{a}$ \\
Esplanada & $4.49 \mathrm{a}$ & $0.21 \mathrm{a}$ & $2.89 \mathrm{a}$ \\
\hline & & Cropping systems & $2.40 \mathrm{~b}$ \\
\hline Intercropping & $6.55 \mathrm{a}$ & $0.37 \mathrm{a}$ \\
Monocropping & $3.15 \mathrm{~b}$ & $0.25 \mathrm{~b}$ & \\
\hline
\end{tabular}

Means followed by different lowercase letters in the column differ statistically by Tukey's test at $5 \%$ probability.

In carrot, we observed higher average values for all characteristics in intercropping systems compared to monocropping (Table 3), which is possibly due to complementarity between the materials tested, resulting in mutual cooperation between cultures.

According to Montezano and Peil (2006), differences in plant architecture can promote the use of available water, light, and nutrients. This explains the complementarity between different cultures, resulting in higher yields through companion cropping (GRANGEIRO et al., 2011).

We found a significant interaction between cultivars of coriander and rocket in the total and commercial productivities of roots and in the productivity of carrot long roots (Table 4).

For coriander cultivars within each rocket cultivar, we observed significant differences between total and commercial productivities in association with Folha Larga cultivar, with higher values for the Verdão cultivar compared to the Português cultivar. The opposite trend was recorded for the productivity of long roots.

On the other hand, for rocket cultivars within each coriander cultivar, there was a significant difference between the mean values of total and commercial productivity in rocket cultivars when intercropped with the Verdão coriander cultivar, with Folha Larga exceeding Cultivada. A different behavior was obtained for productivity of long roots when rocket was associated with the Português coriander cultivar, with the cultivar 'Cultivada' highlighting from 'Folha Larga' cultivar. These differences might be due to competition with coriander and rocket cultivars. 
Table 4. Mean values of total (TPR) and commercial (CPR) productivities of roots and productivity of long roots (PLR) of carrot as a function of cultivar combinations of coriander, carrot and rocket in monocrop and cropping systems.

\begin{tabular}{|c|c|c|c|}
\hline \multirow{3}{*}{$\begin{array}{l}\text { Coriander cultivars in } \\
\text { intercropping }\end{array}$} & \multicolumn{3}{|c|}{ Total productivity $\left(\mathrm{t} \mathrm{ha}^{-1}\right)$} \\
\hline & \multicolumn{3}{|c|}{ Rocket cultivars in intercropping } \\
\hline & Cultivada & & Folha Larga \\
\hline Verdão & $27.33 \mathrm{aB}$ & & $31.82 \mathrm{aA}$ \\
\hline Português & $25.98 \mathrm{aA}$ & & $23.49 \mathrm{bA}$ \\
\hline & \multicolumn{3}{|c|}{ Commercial productivity $\left(\mathrm{t} \mathrm{ha}^{-1}\right)$} \\
\hline Verdão & $25.00 \mathrm{aB}$ & & $28.62 \mathrm{aA}$ \\
\hline Português & $22.12 \mathrm{aA}$ & & $19.50 \mathrm{bA}$ \\
\hline & \multicolumn{3}{|c|}{ Productivity of long roots $\left(\mathrm{t} \mathrm{ha}^{-1}\right)$} \\
\hline Verdão & $5.37 \mathrm{bA}$ & & $6.62 \mathrm{aA}$ \\
\hline Português & $14.25 \mathrm{aA}$ & & $8.75 \mathrm{aB}$ \\
\hline \multirow{2}{*}{ Cultivars } & $\operatorname{TPR}\left(\mathrm{t} \mathrm{ha}^{-1}\right)$ & $\mathrm{CPR}\left(\mathrm{t} \mathrm{ha}^{-1}\right)$ & $\operatorname{PLR}\left(\mathrm{t} \mathrm{ha}^{-1}\right)$ \\
\hline & \multicolumn{3}{|c|}{ Carrot cultivars in intercropping } \\
\hline Brasília & $27.06 \mathrm{a}$ & $23.84 \mathrm{a}$ & $9.11 \mathrm{a}$ \\
\hline \multirow[t]{2}{*}{ Esplanada } & $25.88 \mathrm{a}$ & $22.37 \mathrm{a}$ & $8.50 \mathrm{a}$ \\
\hline & \multicolumn{3}{|c|}{ Carrot cultivars in monocropping } \\
\hline Brasília & $34.50 \mathrm{a}$ & $32.03 \mathrm{a}$ & $8.78 \mathrm{a}$ \\
\hline \multirow[t]{2}{*}{ Esplanada } & $18.32 \mathrm{~b}$ & $16.81 \mathrm{~b}$ & $3.54 \mathrm{a}$ \\
\hline & \multicolumn{3}{|c|}{ Cropping systems } \\
\hline Intercropping & $26.47 \mathrm{a}$ & $23.10 \mathrm{a}$ & $8.80 \mathrm{a}$ \\
\hline Monocropping & $26.42 \mathrm{a}$ & $24.43 \mathrm{a}$ & $6.17 \mathrm{a}$ \\
\hline
\end{tabular}

Means followed by different lowercase letters in the column differ statistically by Tukey's test at $5 \%$ probability.

The values obtained for total and commercial productivities of carrot were 31.82 and $28.62 \mathrm{t} \mathrm{ha}^{-1}$. Our results are in agreement with findings by Oliveira et al. (2004), who studied the agroeconomic performance of lettuce bicropping in intercropping systems with carrot and found values of 32.36 and $25.53 \mathrm{tha}^{-1}$, respectively. On the other hand, Porto et al. (2011), evaluating cultivar combinations of lettuce and rocket in two croppings intercropped with carrot, obtained productivity values in the combinations of Brasilia carrot with Cultivada rocket and Babá de Verão lettuce of $14.7 \mathrm{t} \mathrm{ha}^{-1}$ and $10.0 \mathrm{t} \mathrm{ha}^{-1}$, respectively.

Analyzing the carrot cultivars in intercropping system, we did not find significant differences for any of these characteristics. However, when analyzing the carrot cultivars in monocropping, we observed significant differences in total and commercial root productivity, with the Brasilia cultivar obtaining higher values than Esplanada (Table 4), probably due to higher adaptation abilities of Brasilia to semiarid conditions. Lima et al. (2010), who studied the productive performance of carrot and rocket cultivars in intercropping and monocropping systems and found significant difference between carrot cultivars in monocropping, with higher values for
Brasília cultivar compared to Esplanada.

We recorded significant differences between medium, short, and scrap root production of carrot between cultivars of coriander, with the cultivar Verdão highlighting of the Português in the first two characteristics, and with the Português cultivar outperformed Verdão in the productivity of scrap roots (Table 5). The last result is probably due to the slow growth of Portuguese coriander compared to Verdão, resulting in greater competition between carrot and coriander roots.

We found a significant difference in mean root productivity between carrot cultivars in monocropping, with higher values for the Brasilia cultivar compared to Esplanada (Table 5). These results corroborate in part with those found by Lopes et al. (2008), who evaluated the classified productivity of carrot roots of the cultivars Brasilia, Alvorada, and Esplanada and observed a higher percentage of medium-sized roots in the cultivars Brasilia and Alvorada. On the other hand, these results differ from those found by Oliveira et al. (2004), who studied the agroeconomic performance of eight lettuce cultivars and two carrot cultivars in monocropping and intercropping systems and found no difference between the carrot cultivars Brasília and Alvorada in terms of mean root productivity. 
Table 5. Mean productivity values of medium roots (MR), short roots (SR), and scrap roots (ScR) of carrot as a function of cultivar combinations of coriander, carrot and rocket in monocrop and cropping systems.

\begin{tabular}{cccc}
\hline \multirow{2}{*}{ Cultivar } & MR $\left(\mathrm{t} \mathrm{ha}^{-1}\right)$ & SR $\left(\mathrm{t} \mathrm{ha}^{-1}\right)$ & ScR $\left(\mathrm{t} \mathrm{ha}^{-1}\right)$ \\
\cline { 2 - 4 } & & Coriander cultivars in intercropping & \\
\hline Verdão & $15.49 \mathrm{a}$ & $5.03 \mathrm{a}$ & $2.85 \mathrm{~b}$ \\
Português & $6.92 \mathrm{~b}$ & $1.14 \mathrm{~b}$ & $3.89 \mathrm{a}$ \\
\hline & & Carrot cultivars in intercropping & $3.22 \mathrm{a}$ \\
\hline Brasília & $11.64 \mathrm{a}$ & $3.08 \mathrm{a}$ & $3.51 \mathrm{a}$ \\
Esplanada & $10.77 \mathrm{a}$ & $3.09 \mathrm{a}$ & $3.16 \mathrm{a}$ \\
\hline & & Rocket cultivars in intercropping & $3.57 \mathrm{a}$ \\
\hline Cultivada & $2.93 \mathrm{a}$ & $2.47 \mathrm{a}$ \\
Folha Larga & $10.61 \mathrm{a}$ & $3.25 \mathrm{a}$ & $1.51 \mathrm{a}$ \\
\hline \multicolumn{5}{c}{} & Carrot cultivars in monocropping \\
\hline Brasília & $11.80 \mathrm{a}$ & $6.54 \mathrm{a}$ & $3.37 \mathrm{a}$ \\
Esplanada & $17.98 \mathrm{a}$ & $3.69 \mathrm{a}$ & $1.99 \mathrm{~b}$ \\
\hline \multicolumn{5}{c}{} & Cropping systems \\
\hline Intercropping & $9.58 \mathrm{~b}$ & $5.12 \mathrm{a}$ & $3.19 \mathrm{a}$ \\
Monocropping & $13.78 \mathrm{a}$ & &
\end{tabular}

Means followed by different lowercase letters in the column differ statistically by Tukey's test at $5 \%$ probability.

Regarding the different cultivation systems, there was a significant difference in scrap root production, with higher values observed in the intercropping system $\left(3.37 \mathrm{t} \mathrm{ha}^{-1}\right)$ compared to the monocropping (1.99 $\mathrm{t} \mathrm{ha}^{-1}$ ) (Table 5). This increased scrap root production is due to the amount of plants in this area, causing greater competition between plants in intercropping than in monocropping systems. Our mean values are lower than those found by Porto et al. (2011), who studied the combination of lettuce and rocket cultivars in two croppings in intercropping with carrot and found values of $9.5 \mathrm{t} \mathrm{ha}^{-1}$ for scrap root production.

\section{Agronomic advantage Indices}

There was no significant interaction between cultivars of coriander, carrot, and rocket in terms of agronomic advantage indices (Table 6). However, a significant difference was observed in land equivalent ratio (LER) between the carrot cultivars tested, with the cultivar Esplanada obtaining better results in relation to the Brasilia cultivar. Regardless of the cultivar combinations used in the intercropping, all LER values were greater than one, ranging from 2.49 and 2.98 (Table 6).

These results portray the positive effects of intercropping in food production. Specifically, this means that land consumption for monocropping systems is 149 to $198 \%$ higher than for intercropping systems.

Table 6. Mean values of land equivalent ratio (LER), productive efficiency index (PEI), and score of the canonical variable $(\mathrm{Z})$ as a function of cultivar combinations of coriander, carrot and rocket.

\begin{tabular}{cccc}
\hline \multirow{2}{*}{ Cultivar } & \multicolumn{3}{c}{ Evaluated characteristics } \\
\cline { 2 - 4 } & LER & PEI & $\mathrm{Z}$ \\
\hline & & Coriander cultivars & $1.72 \mathrm{a}$ \\
\hline Verdão & $2.60 \mathrm{a}$ & $0.93 \mathrm{a}$ & $1.33 \mathrm{~b}$ \\
Português & $2.87 \mathrm{a}$ & $0.82 \mathrm{~b}$ & $1.53 \mathrm{a}$ \\
\hline & & Carrot cultivars & $1.52 \mathrm{a}$ \\
\hline Brasília & $2.49 \mathrm{~b}$ & $0.88 \mathrm{a}$ & \\
Esplanada & $2.98 \mathrm{a}$ & $0.87 \mathrm{a}$ & $1.54 \mathrm{a}$ \\
\hline & & Rocket cultivars & $1.50 \mathrm{a}$ \\
\hline Cultivada & $2.87 \mathrm{a}$ & $0.88 \mathrm{a}$ & $0.87 \mathrm{a}$ \\
Folha Larga & $2.60 \mathrm{a}$ & &
\end{tabular}

Means followed by different lowercase letters in the column differ statistically by Tukey's test at $5 \%$ probability.

According to Cecílio Filho et al. (2007), with LER values greater than 1 , intercropping will favor the growth of the companion crops. This indicates that this cropping system more efficiently uses environmental resources.

The highest LER value was 2.98, recorded in combination with the carrot cultivar Esplanada; this was due to lower commercial productivity obtained in the monocropping system. LER values found in our study are higher than those observed by Lima et al. (2014), who studied the agroeconomic viability of intercropping of coriander, lettuce, and rocket under different spatial arrangements and found LER values of up to 1.80. In contrast, Oliveira et al. (2004), evaluating the agroeconomic performance of lettuce cultivars in monocrop and intercropped in strips, 
with two carrot cultivars, found LER values of 2.16 and 2.15 , respectively.

The efficiency of intercropping systems was also determined by the productive efficiency index (PEI) and by the score of the canonical variable (Z). Its determinations in intercropping system reduce a problem essentially multivariate to univariate without loss of information; therefore, its analyses enable the examination of variation patterns of the cultures at the same time.

Highest productive efficiency indices and canonical variable $\mathrm{Z}$ scores were obtained in the intercropping with the coriander cultivar Verdão. These results are due to the fact this cultivar has responded very well in the combinations with the carrot and rocket cultivars studied, thus demonstrating a low interspecific competition in the intercropping.

The highest values found for the productive efficiency index and the score of the canonical variable $Z$ were of 0.93 and 1.72 , respectively, diverging from those found by Lima et al. (2014) who studied the agroeconomic viability of the intercropping system of coriander, lettuce, and rocket under different spatial arrangements and obtained values of 0.97 and 2.76, respectively, in the arrangement 2: 2: 2. Similarly, Bezerra Neto et al. (2007), when analyzing the performance of intercropping systems of carrot and lettuce evaluated by uni - and multivariate methods, observed higher values of 0.79 and 10.85 , respectively.

\section{Economic indicators}

Analyzing the production costs (Table 7), we found that in most combinations of cultivars, the combination with the Verdão cultivar was more promising in relation to the others, i.e. the lower production costs, regardless of the carrot cultivar (Brasilia or Esplanada) or the rocket cultivar (Folha Larga or Cultivada). We also observed that intercropping systems were associated with higher production costs than monocropping systems. This was expected, since cultivation of the associated crops entails additional costs. Souza et al. (2015) reported that differences between production costs are related to expenses of cuts, transportation, grinding, drying, bagging, distribution, and embedding of the plant material, which increased in relation to the quantity factor. This was also observed in our study, where we observed higher production costs in intercropping than in monocropping systems. The higher production costs are related to; the greater amount of plant material used in the intercropping system compared to the material used in the monocropping.

Table 7. Production costs per hectare of combinations of rocket, carrot and coriander cultivars fertilized with $24 \mathrm{t}$ ha $\mathrm{a}^{-1}$ of hairy woodrose and cultivars in monocrops with 12,18 and $14 \mathrm{tha}^{-1}$ of hairy woodrose respectively.

\begin{tabular}{|c|c|c|c|c|c|c|c|c|}
\hline \multirow{2}{*}{ Components } & \multicolumn{8}{|c|}{ Cultivars combinations } \\
\hline & $(\mathrm{CBV})$ & (CBP) & (FLBV) & (FLBP) & $(\mathrm{CEV})$ & (CEP) & (FLEV) & (FLEP) \\
\hline Inputs & 8817.20 & 8792.20 & 8672.20 & 8772.20 & 8852.20 & 8867.20 & 8912.20 & 8927.20 \\
\hline Labor & 16640.00 & 16640.00 & 16640.00 & 16640.00 & 16640.00 & 16640.00 & 16640.00 & 16640.00 \\
\hline Electricity & 233.64 & 233.64 & 233.64 & 233.64 & 233.64 & 233.64 & 233.64 & 233.64 \\
\hline Other expenses & 256.91 & 254.56 & 254.81 & 254.81 & 254.81 & 254.81 & 254.81 & 254.81 \\
\hline $\begin{array}{l}\text { Care and maintenance } \\
1 \% \text { and } 7 \% \mathrm{p} \text {.a. }\end{array}$ & 212.17 & 212.17 & 212.17 & 212.17 & 212.17 & 212.17 & 212.17 & 212.17 \\
\hline Depreciation & 500.38 & 500.38 & 500.38 & 500.38 & 500.38 & 500.38 & 500.38 & 500.38 \\
\hline Taxes and fees & 10.00 & 10.00 & 10.00 & 10.00 & 10.00 & 10.00 & 10.00 & 10.00 \\
\hline Fixed labor & 724.00 & 724.00 & 724.00 & 724.00 & 724.00 & 724.00 & 724.00 & 724.00 \\
\hline $\begin{array}{l}\text { Opportunity costs } 6 \% \\
\text { p.a }\end{array}$ & 1099.84 & 1099.84 & 1099.84 & 1099.84 & 1099.84 & 1099.84 & 1099.84 & 1099.84 \\
\hline Total costs & 28494.14 & 28466.79 & 28347.04 & 28447.04 & 28527.04 & 28542.04 & 28587.04 & 28602.04 \\
\hline \multirow{2}{*}{ Components } & \multicolumn{8}{|c|}{ Cultivars in monocrop } \\
\hline & $(\mathrm{V})$ & \multicolumn{2}{|r|}{ (P) } & $(\mathrm{FL})$ & \multicolumn{2}{|l|}{$(\mathrm{C})$} & (E) & (B) \\
\hline Inputs & 8287.20 & \multicolumn{2}{|c|}{8287.20} & 8399.70 & \multicolumn{2}{|c|}{8269.70} & 8559.70 & 8484.70 \\
\hline Labor & 10600.00 & \multicolumn{2}{|c|}{10600.00} & 9420.00 & \multicolumn{2}{|c|}{9420.00} & 13300.00 & 13300.00 \\
\hline Electricity & 233.64 & \multicolumn{2}{|c|}{233.64} & 233.64 & \multicolumn{2}{|c|}{233.64} & 233.64 & 233.64 \\
\hline Other expenses & 254.81 & \multicolumn{2}{|r|}{254.81} & 254.81 & 179.2 & & 254.81 & 254.81 \\
\hline $\begin{array}{l}\text { Care and maintenance } \\
1 \% \text { and } 7 \% \text { p.a. }\end{array}$ & 212.17 & & 212.17 & 212.17 & 212.1 & & 212.17 & 212.17 \\
\hline Depreciation & 124.83 & & 124.83 & 124.83 & 124.8 & & 495.58 & 495.58 \\
\hline Taxes and fees & 10.00 & & 10.00 & 10.00 & 10.0 & & 10.00 & 10.00 \\
\hline Fixed labor & 724.00 & & 724.00 & 724.00 & 724.0 & & 724.00 & 724.00 \\
\hline $\begin{array}{l}\text { Opportunity costs } 6 \% \\
\text { p.a }\end{array}$ & 1099.00 & & 1099.00 & 1099.00 & 1099.0 & & 1099.00 & 1099.00 \\
\hline Total costs & 21545.65 & & 1545.65 & 20478.15 & 20272.5 & & 4888.90 & 24813.90 \\
\hline
\end{tabular}

CBV - Cultivada, Brasília and Verdão; CBP - Cultivada, Brasília and Português; FLBV - Folha Larga, Brasília and Verdão; FLBP - Folha Larga, Brasília and Português; CEV - Cultivada, Esplanada and Verdão; CEP - Cultivada, Esplanada and Português; FLEV - Folha larga, Esplanada and Verdão; FLEP - Folha larga, Esplanada and Português; C - Cultivada; FL - Folha Larga; E - Esplanada; B - Brasília; V - Verdão; P - Português. 
There was no significant interaction between cultivars of coriander, rocket, and carrot in terms of economic indicators. However, we observed a significant difference between the coriander cultivars in the intercropping, where Verdão cultivar showed higher values than Português in terms of gross income, production costs, net income, rate of return, and profit margin, obtaining $\mathrm{R} \$$ values of 61187.00 , $32,748.0$, and $52.86 \%$, respectively (Table 8 ). The higher economic feasibility of the intercropping system with the coriander cultivar Verdão was most likely related to the higher productivity of this cultivar compared to the cultivar Português.

Table 8. Mean values of gross income (GI), net income (NI), rate of return (RR), and profit margin (PM) functions of cultivar combinations of coriander, carrot and rocket.

\begin{tabular}{lcccc}
\hline \multirow{2}{*}{ Cultivar } & \multicolumn{4}{c}{ Evaluated characteristics } \\
\cline { 2 - 4 } & $\mathrm{RB}\left(\mathrm{R} \$ \mathrm{t} \mathrm{ha}^{-1}\right)$ & $\mathrm{RL}\left(\mathrm{R} \$ \mathrm{t} \mathrm{ha}^{-1}\right)$ & $\mathrm{TR}$ & $\mathrm{IL}(\%)$ \\
\hline Verdão & \multicolumn{4}{c}{ Coriander cultivars } \\
Português & $61,187.00 \mathrm{a}$ & $32,748.00 \mathrm{a}$ & $2.15 \mathrm{a}$ & $52.86 \mathrm{a}$ \\
\hline \multicolumn{5}{c}{ a } \\
\hline Brasília & $52,123.00 \mathrm{~b}$ & $23,559.00 \mathrm{~b}$ & $1.82 \mathrm{~b}$ & $43.84 \mathrm{~b}$ \\
Esplanada & $56,104.00 \mathrm{a}$ & $27,596.00 \mathrm{a}$ & $1.96 \mathrm{a}$ & $47.78 \mathrm{a}$ \\
\hline & $52,206.00 \mathrm{a}$ & $28,710.00 \mathrm{a}$ & $2.00 \mathrm{a}$ & $48.92 \mathrm{a}$ \\
\hline Cultivada & \multicolumn{5}{c}{ Rocket cultivars } \\
Folha Larga & $58,038.00 \mathrm{a}$ & $29,549.00 \mathrm{a}$ & $2.03 \mathrm{a}$ & $50.37 \mathrm{a}$ \\
\hline
\end{tabular}

Means followed by different lowercase letters in the column differ statistically by Tukey's test at $5 \%$ probability.

According to Pinto and Pinto (2012), the economic viability of intercropping systems depends on the patterns of cultivation and on the selection of compatible cultures, since intercropping systems, besides ensuring greater stability in production, reduce risks from climatic adversities characteristic for semiarid regions, thus ensuring adequate income generation for small farmers.

Therefore, the selection of compatible crops for intercropping systems is of major importance in relation to growth habits as well as use of space, light, water, and nutrients (SERAN; BRINTHA, 2010). In this sense, the values obtained in intercropping systems involving the coriander cultivar Verdão represented a greater complementarity between cultures, thus providing greater economic viability.

\section{CONCLUSIONS}

Highest agroeconomic efficiency of intercropping systems was achieved using the combination of the coriander cultivar Verdão, the rocket cultivars Folha Larga or Cultivada, and the carrot cultivars Brasilia or Esplanada.

Regardless of the tested cultivar combinations, production of coriander and rocket in bicropping intercropped with carrot was more efficient than in monocropping systems.

\section{ACKNOWLEDGEMENTS}

We thank the Conselho Nacional de Desenvolvimento Científico e Tecnológico (CNPq) for financial support and the research group of the
Plant Science Department of the Universidade Federal Rural do Semi-Árido (UFERSA) for developing technologies for growing vegetables on family farms.

\section{REFERENCES}

BEZERRA NETO, F. et al. Desempenho agroeconômico do consórcio cenoura $\mathrm{x}$ alface lisa em dois sistemas de cultivo em faixa. Horticultura Brasileira, Brasília, v. 21, n. 4, p. 635-64, 2003.

BEZERRA NETO, F. et al. Desempenho de sistemas consorciados de cenoura e alface avaliados através de métodos uni e multivariados. Horticultura Brasileira, Brasília, v. 25, n. 4, p. 514-520, 2007.

BEZERRA NETO, F. et al. Otimização agroeconômica da cenoura fertilizada com diferentes doses de jitirana. Ciência Agronômica, Fortaleza, v. 45 , n. 2 , p. $305-311,2014$

CECÍLIO FILHO, A. B. et al. Produtividade de alface e rabanete em cultivo consorciado estabelecido em diferentes épocas e espaçamentos entre linhas. Horticultura Brasileira, Brasília, v. 25 , n. 1 , p. $15-19,2007$.

CHARNES, A. et al. Measuring the efficiency of decision-making units. European Journal of Operational Research, Holland, v. 2, n. 6, p. 429-444, 1978.

FERREIRA, D. F. Sisvar: a computer statistical analysis system. Ciência e Agrotecnologia, Lavras, v. 35 , n. 6 , p. 1039-1042, 2011. 
FREITAS, K. K. C. et al. Desempenho agronômico de rúcula sob diferentes espaçamentos e épocas de plantio. Ciência Agronômica, Fortaleza, v. 40, n. 3, p. 449-454, 2009.

GRANGEIRO, L. C. et al. Avaliação agroeconômica das culturas da beterraba e coentro em função da época de estabelecimento do consórcio. Ciência Agronômica, Fortaleza, v. 42, n. 1, p. 242-248, 2011.

LANA, M. M.; VIEIRA, J. V. Fisiologia e manuseio pós-colheita de cenoura. Brasília: Embrapa Hortaliças, 2000. 15 p. (Circular Técnica, 21).

LIMA, J. S. S. et al. Desempenho agroeconômico de coentro em função de espaçamentos e em dois cultivos. Ciência Agronômica, Fortaleza, v. 38, n. 4, p. 407-413, 2007.

LIMA, J. S. S. et al. Productive performance of carrot and rocket cultivars in strip-intercropping system and sole crops. Agrociencia, Montecillo, v. 44 , n. 5 , p. 561-574, 2010.

LIMA, V. I. A. et al. Viabilidade agroeconômica do cultivo consorciado de coentro, alface e rúcula sob diferentes arranjos espaciais. Enciclopédia biosfera, Goiânia, v. 10, n. 18; p. 3060-3069, 2014.

LINHARES, P. C. F. et al. Quantidades e tempos de decomposição da jitirana no desempenho agronômico do coentro. Ciência Rural, Santa Maria, v. 42, n. 2, p. 243-248, 2012.

LINHARES, P. C. F. et al. Resposta da rúcula (Eruca sativa Mill.) Folha Larga a adubação verde com jitirana (Ipomoea glabra L.) incorporada. Revista Verde de Agroecologia e Desenvolvimento Sustentável, Mossoró, v. 3, n. 2, p. 72-77, 2008.

LOPES, W. A. R. et al. Produtividade de cultivares de cenoura sob diferentes densidades de plantio. Revista Ceres, Viçosa, v. 55, n. 5, p. 482-487. 2008.

MONTEZANO, E. M.; PEIL, R. M. N. Sistemas de consórcio na produção de hortaliças. Revista Brasileira de Agrociência, Pelotas, v. 12, n. 2, p. 129-132, 2006.

OLIVEIRA, E. Q. et al. Desempenho agroeconômico do bicultivo de alface em sistema solteiro e consorciado com cenoura. Horticultura Brasileira, Brasília, v. 22, n. 4, p. 712-717, 2004.

OLIVEIRA, L. J. Viabilidade agroeconômica do bicultivo de rúcula e coentro consorciado com cenoura em função de quantidades de jitirana e densidades populacionais. 2012. 102 f. Tese
(Doutorado em Fitotecnia: Área de Concentração em Práticas Culturais) - Universidade Federal Rural do Semi-Árido, Mossoró, 2012.

PINTO, C. M.; PINTO, O. R. O. Avaliação da eficiência biológica e habilidade competitiva nos sistemas de consorciação de plantas. Enciclopédia Biosfera, Goiânia, v. 8, n. 14; p. 105-122, 2012.

PORTO, V. C. N. et al. Combination of lettuce and rocket cultivars in two cultures intercropped with carrots. Horticultura Brasileira, Brasília, v. 29, n. 3, p. 404-411, 2011.

REZENDE, B. L. A. et al. Viabilidade da consorciação de pimentão com repolho, rúcula, alface e rabanete. Horticultura Brasileira, Brasília, v. 24 , n. 1 , p. $36-41,2006$

SEDIYAMA, M. A. N.; SANTOS, I. C.; LIMA, P. C. Cultivo de hortaliças no sistema orgânico. Revista Ceres, Viçosa, v. 61, Sup., p. 829-837, 2014.

SERAN, T. H.; BRINTHA, I. Review on maize based intercropping. Journal of Agronomy, Faislabad, v. 9, n. 3, p. 135-145, 2010.

SILVA, H. D. et al. Viabilidade Agronômica de Consórcios entre Alface e Rúcula no Sistema Orgânico de Produção. Cadernos de Agroecologia, Fortaleza, v. 6, n. 2, p. 1-5, 2011.

SILVA, M. G. et al. Efeito da solarização, adubação química e orgânica no controle de nematóides em alface sob cultivo protegido. Horticultura Brasileira, Brasília, v. 24, n. 4, p. 489-494, 2006.

SOUZA, E. G. F. et al. Rentabilidade da rúcula fertilizada com biomassa de flor-de-seda em função da época de cultivo. Revista Caatinga, Mossoró, v. 28, n. 1 , p. $65-77,2015$. 